\title{
EFEITOS RETROATIVOS DA ESCRITURA PÚBLICA DE UNIÃO ESTÁVEL
}

\section{The effectiveness of the public deed for "non-married couples"}

\section{Alessandra Meneghetti'}

Resumo: A união estável e o casamento são institutos jurídicos que não se confundem, assim como a intenção das pessoas que se unem de maneira informal ou formal. Contudo, a pouca regulamentação do instituto jurídico da união estável conduz à incerteza quanto aos efeitos oriundos da relação afetiva pública, contínua, duradoura e com o objetivo de constituir família, direcionando o intérprete a socorrer-se nas normas do casamento. A entidade familiar formada por meio da união estável precisa receber a atenção necessária para se evitar ou ao menos minimizar os conflitos intrínsecos e externos à relação e, neste contexto, a intervenção do tabelião e do notário mostra-se eficaz para assegurar as
Abstract: The Brazilian provisions named "União Estável", that is a regulation for non-married couples, and marriage, cannot be mistaken, as the intention of the people that decide to live together in a formal or informal manner. Nevertheless, the short regulation related to non-married couples has lead to uncertainties as for the effects resulted from the relationship which is public, continuous, loving, long lasting, aiming to create a family. Hence, leading the officials to apply the laws of marriage. The family created by non-married couples needs to receive the attention necessary in order to avoid or, at least, minimize the disputes that might come up from the relationship itself and the relationship of the family within society. Besides, in this

1 Juíza de Direito da $2^{a}$ Vara Criminal da Comarca de Araranguá. Curso de Pós-Graduação em Direito Notarial e Registral, Universidade Anhanguera - UNIDERP. EAD Polo de Videira, SC. E-mail: sc.videira@lfg.com.br 
regras mínimas que pautarão a união de fato. Partindo-se da matriz constitucional do art. 226, da Constituição Federal, o presente artigo discorreu sobre os institutos jurídicos concernentes ao tema, apoiando-se na doutrina, na jurisprudência, na legislação federal e nas normas editadas pelas Corregedorias do Conselho Nacional de Justiça e dos Tribunais de Justiça do Estado de Santa Catarina, Rio Grande do Sul e São Paulo para, ao final, afirmar que a escritura pública de contrato de união estável poderá produzir efeitos retroativos e erga omnes, desde que sejam observados os requisitos legais e específicos do ato notarial. Com isso, conferir-se-á segurança jurídica, publicidade e eficiência ao ato jurídico realizado por intermédio do tabelião.

Palavras-chave: União estável. Contrato de convivência. Escritura pública. Efeitos jurídicos. context, the intervention of the notary office has been effective ensuring basic regulations that have been grounds for the union itself. The article, under the provision 226 of the Brazilian Federal Constitution, spoke about the provisions related to the subject, researching doctrine, jurisprudence, statute law, and the regulations provided by the "Corregedoria do Conselho Nacional de Justiça", which is similar to internal affairs for the judiciary power in Brazil, and the "Tribunais de Justiça", which are State Courts of Appeal among the federation in Brazil, from the states of Santa Catarina, Rio Grande do Sul, and São Paulo. Finally, the article aims to state that the contract provided for non-married couples executed in the notary office can be effective for the time before the execution and orga omnes, if the legal requirements for the execution are complied. As a result, there will be judicial safety, publicity, and effectiveness to the legal act accomplished by the duty of the notary.

Keywords: Non-married couples. Contract for the relationship. Public deed. Legal effects.

\section{INTRODUÇÃO}

$\mathrm{O}$ art. 226, \& $3^{\circ}$, da Constituição Federal declara que a união estável é família. Essa simples afirmação chama a atenção 
pela obviedade que sintetiza. Contudo, os intérpretes da norma tiveram dificuldades para retirar a união estável do Direito Obrigacional e inseri-la no Direito de Família, porque a união estável, durante muito tempo, foi percebida como sociedade de fato e não como entidade familiar.

Ao receber o tratamento de sociedade de fato, assegurava-se aos companheiros apenas a divisão do patrimônio adquirido "pelo esforço comum", o qual não era presumido, e indenização "pelos serviços prestados" (à companheira), fórmula encontrada pelos intérpretes para evitar o enriquecimento ilícito ao término da união e não deixar nenhum dos companheiros desamparado. Esse pensamento foi sintetizado no Enunciado n 380 da Súmula do Supremo Tribunal Federal: "Comprovada a existência de sociedade de fato entre os concubinos, é cabível a sua dissolução judicial, com a partilha do patrimônio adquirido pelo esforço comum.” Todavia, a Constituição Federal estancou a problemática. Não há mais discussão sobre a natureza do instituto e as uniões de fato receberam a proteção do Estado como família.

As Leis n 8.971/1994, n 9.278/1996 e o Código Civil regulamentaram timidamente a união estável ao estabelecerem regras quanto à partilha dos bens, alimentos e sucessão. Contudo, ao se comparar com as regras para o casamento, ver-se-á que os companheiros ainda estão desprotegidos, porque as questões atinentes ao estado civil, maneira de constituição, efeitos patrimoniais e pessoais não foram definidas por completo, forçando o intérprete a socorrer-se nas regras do casamento na medida em que a Constituição Federal não distinguiu as duas espécies de família, interpretação constitucional que irradia efeitos para a legislação regulamentadora.

A união estável é fato jurídico que se constitui no tempo. Os companheiros podem optar pela formalização de pacto ou contrato de convivência a fim de dispor de regras diferentes das previstas nas citadas leis. O contrato de convivência pode ser por instrumento particular ou público, servindo de prova à 
união, já que esta não se constitui pelo pacto, mas pela convivência pública, contínua, duradoura e com o objetivo de constituir uma família (art. $1^{\circ}$ da Lei nº 9.278/96).

Contudo, veda-se a inserção da data do começo da união de fato nos contratos ou escrituras, ao argumento de que somente por meio de ação judicial é possível produzir provas da união, evitando-se, assim, eventuais fraudes que a união poderá encobrir. Essa proibição é expressa pela maioria dos doutrinadores e também nas normas das Corregedorias dos Tribunais Estaduais, como se pode verificar no art. 567, § $3^{\circ}$, do Código de Normas da Corregedoria-Geral da Justiça do Estado de Santa Catarina que dispõe sobre a conversão da união estável em casamento.

Dessarte, o objetivo desse artigo é demonstrar que o excesso de precaução trará efeito contrário ao desejado, porque é mais seguro às relações jurídicas que os pactos contenham a data que os companheiros indicaram como início da relação afetiva, principalmente quanto aos efeitos patrimoniais advindos da relação. Além do mais, a união estável se prova com os requisitos legais e a formalização mediante pacto é apenas um meio de prova sem presunção absoluta de veracidade. Logo, contestada a união estável, há meios de derruí-la sem prejuízos a terceiros.

Afirma-se que o notário possui meios para perquirir a data de início da união estável, solicitando aos companheiros a certidão atualizada do registro do pacto de convivência ou da escritura pública no Registro de Títulos e Documentos para provar a autenticidade da data ou, à falta deste, a presença de duas testemunhas.

A escolha pelo estudo desse tema surgiu da necessidade de dar transparência e visibilidade à relação de fato dos companheiros, bem como defender que o excesso de proteção e desconfiança do Legislador ocasiona travamento, burocracia e demora indesejada aos companheiros, além de crescentes ações judiciais para discutir as cláusulas da união de fato e seus efeitos. 


\section{A UNIÃO ESTÁVEL INSERIDA NO DIREITO DE FAMÍLIA}

$\bigcirc$ art. 226, § $3^{\circ}$, da Constituição Federal preceitua: "Para efeito da proteção do Estado, é reconhecida a união estável entre o homem e a mulher como entidade familiar, devendo a lei facilitar sua conversão em casamento.” Ao assegurar proteção constitucional à união estável e defini-la como entidade familiar o legislador constituinte reparou a danosa interpretação até então conferida ao instituto, retirando-o do direito obrigacional para recolocá-lo no seu lugar, isto é, dentro do direito de família, ao lado do casamento, das uniões homoafetivas e dos vínculos monoparentais (entidade familiar formada por qualquer dos pais e seus descendentes).

O Enunciado $n^{\circ} 380$ da Súmula do Supremo Tribunal Federal sintetizou o pensamento do Judiciário durante muito tempo ao considerar como sociedade de fato as uniões não matrimoniais: "Comprovada a existência de sociedade de fato entre os concubinos, é cabível a sua dissolução judicial, com a partilha do patrimônio adquirido pelo esforço comum." Garantia-se aos companheiros apenas efeitos patrimoniais de natureza obrigacional, como a partilha dos bens e indenização pelos serviços prestados nas hipóteses de dissolução da união. Paulo Luís Netto Lôbo afirma que esse Enunciado foi construído pela doutrina e jurisprudência na vigência da Constituição Federal de 1946 para

tangenciar a vedação de tutela legal das famílias constituídas sem casamento, de modo a encontrar-se alguma proteção patrimonial a, frequentemente, mulheres abandonadas por seus companheiros, após anos de convivência afetiva. Como não era possível encontrar fundamento no direito de família, em virtude da vedação constitucional, socorreu-se do direito obrigacional, segundo o modelo das sociedades mercantis ou civis de constituição incompleta, ou seja, das 'sociedades de fato'. Essa construção é típica do que determinada 
escola jurídica italiana denominou 'uso alternativo do direito'. Os efeitos da Súmula limitam-se exclusivamente ao plano econômico ou patrimonial. ${ }^{2}$

Todavia, as Leis n 8.971/1994, n 9.278/1996 e o Código Civil (CC) regulamentaram a norma constitucional ao disporem sobre os efeitos pessoais e patrimoniais da união estável, reafirmando o lugar do instituto no direito de família na medida em que "[...] as regras de direito de família afetam o indivíduo dentro daquele núcleo social, relativamente pequeno, em que ele nasce, cresce e se desenvolve disciplinando suas relações de ordem pessoal e patrimonial." 3

É na família que a união estável encontra sua natureza e existência por ser relação de afeto construída dia após dia. E foi a Constituição Federal que voltou a atenção às pessoas que se unem pela afetividade e não pela lei ou pela affectio societatis.

$\mathrm{O}$ art. 1.723 do Código Civil conceitua união estável: "É reconhecida como entidade familiar a união estável entre o homem e a mulher, configurada na convivência pública, contínua e duradoura e estabelecida com o objetivo de constituição de família." O legislador não é afeiçoado a conceitos e também não é tarefa sua fazê-lo, porque à doutrina reserva-se a tarefa de definir, conceituar, aproximar, criticar e contextualizar as leis, assim como ao Judiciário a missão de interpretar e aplicar as normas.

O civilista Silvio Rodrigues conceituou união estável como:

[...] a união do homem e da mulher, fora do matrimônio, de caráter estável, mais ou menos prolongada, para o fim da satisfação sexual, assistência mútua e dos filhos comuns e que implica uma presumida fidelidade recíproca entre a mulher e o homem. (ob. cit., p. 259).

2 LÔBO, Paulo Luiz Netto. Entidades familiares constitucionalizadas: para além do numerus clausus. Revista Brasileira de Direito de Família. Porto Alegre. v.3, n. 12, jan./mar., p. 40-65, 2002.

3 RODRIGUES, Silvio. Direito civil: direito de família. v. 6, 28 ed., São Paulo: Saraiva, 2004 , p. 3. 
A união estável é também conhecida como concubinato e Rodrigues (2004) diferencia o concubinato puro do impuro, afirmando que é concubinato impuro o vínculo adulterino, sem estabilidade e passageiro entre pessoas impedidas de casar. Para o autor, é união ilegítima sem proteção jurídica aos partícipes.

O Ministro Marco Aurélio, do Supremo Tribunal Federal, também distinguiu companheira e concubina:

Companheira e concubina. Distinção. Sendo o Direito uma verdadeira ciência, impossível é confundir institutos, expressões e vocábulos, sob pena de prevalecer a babel. [...] A proteção do Estado à união estável alcança apenas as situações legítimas e nestas não está incluído o concubinato. [...] A titularidade da pensão decorrente do falecimento de servidor público pressupõe vínculo agasalhado pelo ordenamento jurídico, mostrando-se impróprio o implemento de divisão a beneficiar, em detrimento da família, a concubina. ${ }^{4}$

E também não é união estável a convivência de criança, vítima de crime contra a dignidade sexual resultando gravidez, com o agressor. A decisão é do Ministro Joaquim Barbosa, também do Supremo Tribunal Federal (recentemente aposentado):

Convívio que não pode ser caracterizado como união estável, nem mesmo para os fins do art. 226, $\S 3^{\circ}$, da Constituição Republicana, que não protege a relação marital de uma criança com seu opressor, sendo clara a inexistência de um consentimento válido, neste caso. ${ }^{5}$

Rodrigo da Cunha Pereira, da mesma maneira, também distingue concubinato puro e impuro, preferindo as expressões não-adulterino e adulterino. Afirma que o Código Civil diferenciou o concubinato da união estável nos arts. 1.723 e 1.727 .

4 BRASIL. Supremo Tribunal Federal. RE 590.779. Relator Ministro Marco Aurélio. Decisão prolatada em 10-2-2009. DJE de 27-3-2009.

5 BRASIL. Supremo Tribunal Federal. RE 418.376, Relator para o Acórdão Ministro Joaquim Barbosa. Acórdão prolatado em 9-2-2006. DJ de 23-3-2007. 
Em síntese, união estável é a relação afetivo-amorosa entre um homem e uma mulher, não-adulterina e não-incestuosa, com estabilidade e durabilidade, vivendo sob o mesmo teto ou não, constituindo família sem o vínculo do casamento civil. E concubinato é a relação entre homem e mulher na qual existem impedimentos para o casamento. ${ }^{6}$

Para Sílvio de Salvo Venosa "Não é qualquer relacionamento fugaz e transitório que constitui a união protegida;" O civilista, amparado no art. $1^{\circ}$ da Lei $n^{\circ} 9.278 / 1996$ e artigo 1.723 do CC, enumera esses elementos como definidores da união estável: a) estabilidade, caracterizada pelo relacionamento duradouro; b) continuidade, assinalada na ausência de interrupções; c) diversidade de sexos; d) publicidade; e) objetivo de constituir a família.

Importante mencionar que o Supremo Tribunal Federal reconheceu como união estável a união entre pessoas do mesmo sexo, atribuindo à entidade familiar a proteção quanto aos efeitos pessoais e patrimoniais. ${ }^{8}$

Não obstante as divergências conceituais, observa-se que o intérprete da lei não oscila em afirmar que a união estável é família e seus elementos constitutivos precisam ser contextualizados e vivificados de acordo com as mudanças comportamentais e os desejos do principal elemento formador desse fato jurídico: a pessoa. O Ministro Sálvio Figueiredo citado por Rodrigo da Cunha Pereira, afirmou "[...] há de interpretar as leis com o espírito ao nível de seu tempo, isto é, mergulhado na viva realidade ambiente, e não acorrentá-lo a algo do passado, nem perdido em alguma paragem, mesmo provável, do distante futuro." (p.106). ${ }^{9}$

6 PEREIRA, Rodrigo da Cunha. Concubinato e união estável. 7 ed., Belo Horizonte: Del Rey, 2004, p. 28-29.

7 VENOSA, Sílvio de Salvo. Direito civil: direito de família. v. 6, 7 ed., São Paulo: Atlas, 2007, p. 39.

8 BRASIL. Supremo Tribunal Federal. ADPF 132 e ADIN 4.277. Relator Ministro Carlos Ayres Brito. Decisão prolatada em 5-5-2011.

9 Ob. cit., p. 106. 
Para a Lei n 3.071/1916, antigo Código Civil, família era sinônimo de casamento. Por influência da religião, o Estado cuidava apenas da família instituída pelo matrimônio, protegendo os cônjuges e os filhos gerados da união matrimonializada. Deixava ao desamparo os concubinos e filhos gerados de outras relações afetivas distintas, algumas até mesmo concomitantes ao casamento.

No entanto, com o art. 226, § $3^{\circ}$, da Constituição Federal de 1988 e com a vigência das Leis $n^{\circ} 8.971 / 1994$, n 9.278/1996 e n ${ }^{\circ}$ 10.406/2002 (Código Civil atual), o direito passou a notar e cuidar de outras formas de família, editando normas mínimas a fim de regulamentá-las. Com isso, ficou claro o pensamento de distinguir e não confundir casamento e união estável. As pessoas optam pela convivência informal de maneira consciente ou não, pois, como é fato jurídico construído no tempo, o relacionamento afetivo poderá evoluir para união estável sem que os conviventes percebam - embora desejem - e assim formem uma família. A informalidade na constituição é a principal diferença com o casamento, ainda que a relação afetiva apoie-se nos deveres de lealdade, respeito e assistência (art. 1.724 do Código Civil).

A mínima regulamentação do instituto não é argumento suficiente para equipará-lo ao casamento, porque o legislador constituinte quis distinguir os institutos além de preceituar a não hierarquia entre ambos. Somente na falta de norma específica para a união estável é que o intérprete socorrer-se-á das normas relativas ao casamento, em legítima hermenêutica constitucional, pois, como a Constituição não distinguiu a lei não poderá fazê-lo para não ser inconstitucional e infringir o princípio da isonomia.

Por essa forma, apenas os direitos conferidos aos cônjuges são extensivos aos companheiros, ao passo que, quanto aos deveres, não se admite interpretação analógica. Exemplo disso são os impedimentos para casar. $\mathrm{O}$ art. $1.723, \S 1^{\circ}$, do Código Civil dispõe: "A união estável não se constituirá se ocorrerem os 
impedimentos do art. 1.521; não se aplicando a incidência do inciso VI no caso de a pessoa casada se achar separada de fato ou judicialmente." Assim, veda-se tanto o casamento quanto a união estável para as pessoas que estiverem em uma das situações do art. 1.521 do Código Civil. Porém, as causas suspensivas para o casamento não se aplicam à união estável porque não previstas pelo legislador para as uniões de fato.

Maria Berenice Dias sustenta que "A consagração e a proteção assegurada às entidades familiares constituem garantia constitucional. Assim, não podem sofrer limitações ou restrições da legislação ordinária." ${ }^{10}$ Apresenta posicionamento acentuado quanto à isonomia de tratamento constitucional:

Quando a lei trata de forma diferente a união estável em relação ao casamento, é de se ter simplesmente tais referências como não escritas. Sempre que o legislador deixa de nominar a união estável frente a prerrogativas concedidas ao casamento, outorgando-lhe tratamento diferenciado, devem tais omissões ser tidas por inexistentes, ineficazes e inconstitucionais. Do mesmo modo, todo texto em que é citado o cônjuge, é necessário ler-se cônjuge ou companheiro. ${ }^{11}$

União estável e casamento são espécies de família. Não há mais dúvidas quanto a essa assertiva. A reduzida regulamentação da união estável não a equipara ao casamento, ao contrário, reforça a intenção do legislador em diferenciá-los.

\section{OS PACTOS DE CONVIVÊNCIA E OS REGISTROS PÚBLICOS}

A formalização de regras quanto à convivência entre os companheiros pode ser feita por meio de contrato particular de convivência ou escritura pública.

10 Ob. cit., p. 172.

11 Ob. cit., p. 172. 
O contrato particular de convivência é aconselhável para reger as relações patrimoniais da família, pois o patrimônio é o principal ponto de discussão nas hipóteses de dissolução da união, principalmente na morte de um dos companheiros. $\mathrm{O}$ art. 1.725 do Código Civil assenta: "Na união estável, salvo contrato escrito entre os companheiros, aplica-se às relações patrimoniais, no que couber, o regime da comunhão parcial de bens.” Francisco José Cahali citado por Rodrigo da Cunha Pereira conceitua contrato particular de convivência como "o instrumento pelo qual os sujeitos de uma união estável promovem regulamentações quanto aos reflexos da relação." 12 Euclides de Oliveira citado por Sálvio de Figueiredo Teixeira assim conceituou o contrato escrito de convivência:

Em suma, a formalização da vida em comum dos companheiros ou conviventes mediante contrato escrito, ainda que não essencial e com as restrições apontadas, mostra-se recomendável e útil para sinalizar as regras do tempo de vida em comum, especialmente na esfera da formação do patrimônio e sua administração. $\mathrm{O}$ instrumento escrito, tanto no início como no término da convivência certamente prevenirá muitos litígios, permitindo o acertamento amigável das relevantes questões resultantes dos efeitos jurídicos da entidade familiar oriunda da união estável. ${ }^{13}$

Para a formalização do contrato, os companheiros observarão os requisitos gerais de validade dos atos e negócios jurídicos previstos no art. 104 do Código Civil, e como pressupostos específicos observarão o disposto nos arts. 1.723 a 1.727 do Código Civil e nas Leis n 8.971/1994, n 9.278/1996, atentando-se principalmente para os impedimentos do art. 1.521 do Código Civil extensível à união estável por força do art. 1.723, $\S 1^{\circ}$, do Código Civil.

12 Ob. cit. p. 38.

13 TEIXEIRA, SÁLVIO DE FIGUEIREDO. Comentários ao novo Código Civil: da união estável, da tutela e da curatela. v. XX, $1^{\text {a }}$ ed., Rio de Janeiro: Forense, 2007, p. 172-173. 
O contrato particular de convivência poderá ser inscrito no Registro de Títulos e Documentos com a finalidade probatória, de conservação do documento e de autenticidade da data, nos exatos termos do art. 127, inciso VII, da Lei n 6.015, de 31 de dezembro de 1973, art. 221, do Código Civil, e artigo 597, inciso II, do Código de Normas da Corregedoria-Geral da Justiça do Estado de Santa Catarina. O Desembargador João Loureiro Ferreira, do Tribunal de Justiça do Estado do Rio Grande do Sul, citado por Sálvio de Figueiredo Teixeira, admitiu o registro do contrato ainda em 1992:

União estável - Contrato - Possibilidade de registro no Ofício de Títulos e Documentos com base no art. 127, VII, da Lei 6.015 para fins exclusivos de conservação, prova e autenticidade da data.

[...]

Não se pleiteia a constituição ou a publicidade de um estado civil ou de um pré-estado [...] Ora, se se cuida ou não de união estável é matéria que pode ser questionada no futuro porque os registros não subsistem aos planos de existência e validade. ${ }^{14}$

Como consequência desse registro, os companheiros possuirão documento comprobatório das regras que escolheram para a união estável, da data de início da união e também darão publicidade à união de fato, informações úteis como início de prova da união de fato (nos termos do art. 1.723 do Código Civil).

Ainda, é importante mencionar que o efeito do registro do contrato também é para terceiros, embora o registro seja facultativo. A publicidade é um dos elementos para o reconhecimento da união estável e a intenção dos companheiros ao registrar o contrato é justamente tornar pública a formalização das regras da relação.

A escritura pública "é sempre o instrumento do ato jurídico praticado em presença do tabelião." ${ }^{15}$. O notário ou tabelião é o

14 Ob. cit., p. 175-176.

15 THEODORO JÚNIOR, Humberto. Comentários ao novo Código Civil: dos atos jurídicos lícitos, dos atos ilícitos, da prescrição e da decadência, da prova. v. III, tomo II. $4^{\text {a }}$ ed., Rio de Janeiro: Forense, 2008, p. 508. 
oficial competente para a criação do documento público, o qual é elaborado com as declarações prestadas pelos companheiros ao agente delegado do serviço público (art. 236 da Constituição Federal), responsável pelo cumprimento das formalidades legais à elaboração do documento público e não pela veracidade das declarações que lhe são prestadas.

Os companheiros que optarem pela escritura pública para descreverem as regras de convivência deverão atender as exigências do art. 215 do Código Civil, as quais serão feitas pelo tabelião no ato de elaboração do documento público, bem como as exigências específicas já apontadas para o contrato particular de convivência expostas acima.

Com a edição do Provimento n 37 do Conselho Nacional de Justiça ${ }^{16}$ (assinado na data de 7 de julho de 2014, ou seja, durante a elaboração deste artigo científico) os companheiros que escolherem a escritura pública, ao invés do contrato particular de convivência, poderão requerer o registro da união estável no Registro Civil de Pessoas Naturais, Livro E, nos termos dos arts. $1^{\circ}$ e $2^{\circ}$ do Provimento. ${ }^{17}$

Nos termos do Provimento, o tabelião, ao elaborar a escritura pública de contrato de união estável deverá observar também os requisitos específicos listados no artigo $2^{\circ}$, letras "a" a "g" (com exceção das disposições relativas à sentença judicial), para que o documento possa ser levado ao Registro Civil de Pessoas Naturais e produzir efeitos patrimoniais entre os companheiros (art. $4^{\circ}$ ). O oficial possui ainda o encargo de anotar o registro da união estável nos atos anteriores, com remissões recíprocas ou comunicá-lo ao Oficial do Registro Civil das Pessoas

16 A conformidade constitucional do texto do Provimento não será discutida neste artigo.

17 Art. $1^{\circ}$. É facultativo o registro da união estável prevista nos arts. 1.723 a 1.727 do Código Civil, mantida entre o homem e a mulher, ou entre duas pessoas do mesmo sexo. Art. $2^{\circ}$. O registro da sentença declaratória de reconhecimento e dissolução, ou extinção, bem como da escritura pública de contrato e distrato envolvendo união estável, será feito no Livro "E”, pelo Oficial do Registro Civil de Pessoas Naturais da Sede, ou, onde houver, no $1^{\circ}$ Subdistrito da Comarca em que os companheiros têm ou tiveram seu último domicílio, devendo constar: [...]. 
Naturais em que estiverem os registros primitivos dos companheiros, bem como deverá averbar no registro da união estável o óbito, o casamento, a constituição de nova união estável e a interdição dos companheiros.

À semelhança do contrato particular, a escritura pública também poderá ser inscrita no Registro de Títulos e Documentos (art. 127, inciso VII, da Lei $\mathrm{n}^{\circ}$ 6.015/73, art. 215 do Código Civil e art. 599, inciso II, do Código de Normas da Corregedoria-Geral da Justiça do Estado de Santa Catarina) para a produção dos efeitos jurídicos já descritos quanto ao registro do contrato particular de união estável.

As normas administrativas ${ }^{18}$ atribuem eficácia limitada ao contrato particular de convivência e à escritura pública de contrato de união estável quanto aos efeitos patrimoniais com relação a terceiros, além de não preverem a possibilidade de inserção da data de início da união estável e vedarem textualmente o lançamento da data de início nas hipóteses de conversão da união estável em casamento. ${ }^{19}$

Contudo, especificamente quanto à eficácia para terceiros da escritura pública de contrato de união estável (art. $5^{\circ}$ do Provimento 37/2014), afirma-se que o Conselho Nacional de Justiça, ao restringir a eficácia do ato notarial, contrariou a essência legal do documento público e os princípios da segurança jurídica e da publicidade da atividade notarial.

Os atos que o tabelião ou notário e o oficial de registro elaboram e certificam no exercício de suas funções são dotados de fé pública (art. $4^{\circ}$ da Lei n $8.935 / 94$ ) e, por força da publi-

18 Normas administrativas são aquelas editadas pelo Poder Judiciário, por intermédio das Corregedorias, no exercício da função fiscalizatória dos serviços notariais e de registro (art. 236, $\S 1^{\circ}$, da Constituição Federal).

19 A vedação é encontrada no art. $5^{\circ}$ do Provimento $n^{\circ} 37$ do Conselho Nacional de Justiça, no art. 567, $\S 3^{\circ}$, do Código de Normas da Corregedoria-Geral da Justiça do Estado de Santa Catarina, assim como no art. 87.5 do Tomo II das Normas de Serviço Extrajudiciais da Corregedoria Geral da Justiça do Estado de São Paulo, ao passo que a Consolidação Normativa Notarial e Registral da Corregedoria-Geral da Justiça do Estado do Rio Grande do Sul permite apenas ao juiz inserir a data de início da união estável que será levada à conversão desta em casamento (art. 152). 
cidade do ato notarial, a eficácia do ato ou negócio jurídico é erga omnes e não apenas entre as partes. A publicidade, ao lado da autenticidade, segurança e eficácia do ato jurídico é basilar e inerente aos registros públicos (artigo $1^{\circ}$ da Lei $n^{\circ} 8.935 / 94$ ) e não pode ser afastada ou restringida por ato administrativo do Poder Judiciário. Humberto Theodor Júnior ensinava que

O negócio realizado nas notas de um tabelião é público desde o momento de sua celebração, donde sua eficácia natural não só inter partes como também em relação a terceiros. $\mathrm{O}$ que se ultima por escritura particular vale e obriga entre as partes, mas, por si só, não pode ser oposto a terceiros. Se lançado, porém, no registro público de títulos e documentos, ou outro registro público especial (como, v.g., a Junta Comercial, Registro de Protestos, Registro de Imóveis etc.), adquirirão oponibilidade erga omnes. ${ }^{20}$

Para o autor, a inscrição registral "[...] é apenas ato de publicidade, embora de relevante importância jurídica, visto que é a partir dele que o negócio das partes adquirirá força para ser oposto a terceiros." ${ }^{21}$

Dessarte, é possível que o tabelião insira a data de início da união de fato na escritura pública quando os companheiros apresentarem certidão do registro do contrato no Registro de Títulos e Documentos ou duas testemunhas que afirmem que os companheiros convivem de maneira pública, contínua e duradoura e que desconhecem a existência de impedimentos matrimoniais. Com isso, os efeitos do reconhecimento da união de fato retroagirão à data constante no contrato particular de convivência registrado ou na data afirmada pelos companheiros e ratificada pelas testemunhas.

A importância dos efeitos retroativos e para terceiros à escritura pública de contrato de união estável reflete-se nos negócios jurídicos celebrados por apenas um dos compa-

21 Ob. cit., p. 525-526. 
nheiros. Como exemplo, recentemente o Superior Tribunal de Justiça decidiu que não é necessário outorga uxória do(a) companheiro(a) fiador(a) no contrato de locação, a qual é exigida para os cônjuges pelo art. 1.647, inciso III, do Código Civil. Se o terceiro contratante buscar a informação de existência da união de fato no Registro de Títulos e Documentos, no Tabelionato ou no Registro Civil das Pessoas Naturais, poderá exigir a assinatura dos companheiros na fiança prestada em contrato ou no aval aos títulos de crédito evitando ação judicial para discutir a dispensa ou não da garantia. ${ }^{22}$ Nesse sentido, o delegado do serviço público contribuirá para a segurança das relações jurídicas e a minimização das demandas judiciais atinentes às uniões de fato, partindo-se da concepção de que é missão sua prevenir litígios futuros ao orientar as partes na elaboração dos atos.

22 BRASIL. Superior Tribunal de Justiça. DIREITO CIVIL-CONSTITUCIONAL. DIREITO DE FAMÍLIA. CONTRATO DE LOCAÇÃO. FIANÇA. FIADORA QUE CONVIVIA EM UNIÃO ESTÁVEL. INEXISTÊNCIA DE OUTORGA UXÓRIA. DISPENSA. VALIDADE DA GARANTIA. INAPLICABILIDADE DA SÚMULA N. 332/STJ. 1. Mostra-se de extrema relevância para a construção de uma jurisprudência consistente acerca da disciplina do casamento e da união estável saber, diante das naturais diferenças entre os dois institutos, quais os limites e possibilidades de tratamento jurídico diferenciado entre eles. 2. Toda e qualquer diferença entre casamento e união estável deve ser analisada a partir da dupla concepção do que seja casamento - por um lado, ato jurídico solene do qual decorre uma relação jurídica com efeitos tipificados pelo ordenamento jurídico, e, por outro, uma entidade familiar, dentre várias outras protegidas pela Constituição. 3. Assim, o casamento, tido por entidade familiar, não se difere em nenhum aspecto da união estável - também uma entidade familiar -, porquanto não há famílias timbradas como de "segunda classe" pela Constituição Federal de 1988, diferentemente do que ocorria nos diplomas constitucionais e legais superados. Apenas quando se analisa o casamento como ato jurídico formal e solene é que as diferenças entre este e a união estável se fazem visíveis, e somente em razão dessas diferenças entre casamento - ato jurídico - e união estável é que o tratamento legal ou jurisprudencial diferenciado se justifica. 4. A exigência de outorga uxória a determinados negócios jurídicos transita exatamente por este aspecto em que o tratamento diferenciado entre casamento e união estável é justificável. É por intermédio do ato jurídico cartorário e solene do casamento que se presume a publicidade do estado civil dos contratantes, de modo que, em sendo eles conviventes em união estável, hão de ser dispensadas as vênias conjugais para a concessão de fiança. 5. Desse modo, não é nula nem anulável a fiança prestada por fiador convivente em união estável sem a outorga uxória do outro companheiro. Não incidência da Súmula n. 332/STJ à união estável. 6. Recurso especial provido. Recurso especial n. 1.299.866. Linea G Empreendimentos de Engenharia Ltda. e Carlos Levino Vilanova. Relator: Ministro Luis Felipe Salomão. DJe 21 mar. 2014. 


\section{CONCLUSÃO}

A união estável, durante muito tempo, foi vista como união espúria entre pessoas impedidas de casar. Contudo, a insistência dos casais de conviverem de maneira pública, contínua e duradoura sem o vínculo matrimonial demonstrou ao legislador e ao intérprete que há várias formas de família e a união estável é uma delas, ao lado do casamento e das famílias monoparentais. Desse modo, as uniões de fato foram inseridas no Direito de Família por meio do art. 226, § $3^{\circ}$, da Constituição Federal, também conceituadas como entidade familiar.

União estável, união de fato ou concubinato são os muitos nomes emprestados às uniões de pessoas não matrimonializadas. Contudo, todos esses nomes traduzem a união de pessoas como entidade familiar passível de proteção jurídica quanto aos efeitos pessoais e patrimoniais.

O desafio do intérprete da norma que timidamente regulamentou as uniões de fato é, em autêntica hermenêutica constitucional, conferir ao companheiro os mesmos direitos que o legislador concedeu ao cônjuge, sem distinção para aqueles que convivem em união estável e para aqueles que realizaram o casamento civil.

Nesse contexto, a intervenção da atividade notarial na orientação e na formalização de contrato particular de convivência ou escritura pública de contrato de convivência, bem como no registro desses documentos nas serventias específicas, tem auxiliado e muito na segurança dos atos jurídicos e na desjudicialização de conflitos atinentes à relação patrimonial entre os companheiros e terceiros, na medida em que a publicidade registral revela aos interessados as regras escolhidas pelos companheiros para regerem a relação.

O tabelião possui condições de inserir a data de início da união estável desde que os companheiros apresentem certidão do Registro de Títulos e Documentos contendo esta informação, a qual será obtida pelo registrador por meio de consulta 
ao contrato particular de união estável ou da escritura pública de contrato de união estável inscritas na serventia, ou com a exigência de duas testemunhas que declarem o início da união de fato, lembrando que o tabelião é responsável pelo cumprimento das formalidades do ato notarial e não pelas declarações dos interessados.

Com isso, os atos de formalização da união estável conferirão efeitos patrimoniais retroativos e em relação a terceiros, os quais são inerentes à essência da união estável, à publicidade dos atos notariais e à segurança das relações jurídicas. Muito embora o Provimento $n^{\circ} 37 / 2014$ do Conselho Nacional de Justiça tenha limitado os efeitos da escritura pública, o estudo demonstrou que o excesso de precaução da legislação é, ao mesmo tempo, louvável e embaraçador, porque o tabelião é profissional do direito dotado de capacidade jurídica para a lavratura do ato.

O estudo do tema evidenciou a necessidade de regulamentação pormenorizada das relações de fato, pois o número de casais que tem optado por conviver em união estável, ao invés de casar, já superou o número de casamentos, como revelou a pesquisa do IBGE desse ano. E, por consequência, o número de ações judiciais também tem crescido muito, principalmente quando o casal resolve por termo à união.

\section{REFERÊNCIAS}

ANTUNES, Luciana Rodrigues. Introdução ao Direito Notarial e Registral. Minas Gerais. Disponível em: <http://www.jusnavegandi.com.br/>. Acesso em: 31 março 2014.

CASSETTARI, Christiano. Separação, divórcio e inventário por escritura pública. 6 ed., Rio de Janeiro: Forense, São Paulo: Método, 2013.

CENEVIVA, Walter. Lei dos registros públicos comentada. 19 ed., São Paulo: Saraiva, 2009. 
DIAS, Maria Berenice. Manual de direito das famílias. 6 ed., São Paulo: RT, 2010.

LÔBO, Paulo Luiz Netto. Entidades familiares constitucionalizadas: para além do numerus clausus. Revista Brasileira de Direito de Família. Porto Alegre. v.3, n. 12, jan./mar., 2002.

LOUREIRO, Luiz Guilherme. Registros públicos: teoria e prática. São Paulo: Método, 2010.

OLIVEIRA. Elci Simões de. O juiz e o serviço extrajudicial. Amazonas. Disponível em: <http://www.tj.am.gov.br/>. Acesso em: 6 abril 2014.

PELUSO, Cezar. Código Civil comentado: doutrina e jurisprudência. 7 ed., Barueri, SP: Manole, 2013.

PEREIRA, Rodrigo da Cunha. Concubinato e união estável. 7 ed., Belo Horizonte: Del Rey, 2004.

RODRIGUES, Silvio. Direito civil: direito de família. v. 6., 28 ed., São Paulo: Saraiva, 2004.

SOARES. Alexandre Artur Mendes. O princípio da eficiência e o titular da serventia extrajudicial. Minas Gerais, ano III, n. 11, 2007. Disponível em: <http://aplicacao.mpmg.mp.br/>. Acesso em: 25 março 2014.

TEIXEIRA, SÁlVIO DE FIGUEIREDO. Comentários ao novo Código Civil: da união estável, da tutela e da curatela. v. XX, 1ª ed., Rio de Janeiro: Forense, 2007.

THEODORO JÚNIOR, Humberto. Comentários ao novo Código Civil: dos atos jurídicos lícitos, dos atos ilícitos, da prescrição e da decadência, da prova. v. III, tomo II. 4a ed., Rio de Janeiro: Forense, 2008.

TOMASZEWSKI, Adauto de Almeida. Comentários à Lei dos Registros Públicos. Florianópolis: Conceito Editorial, 2010.

VENOSA, Sílvio de Salvo. Direito civil: direito de família. v. 6, 7 ed., São Paulo: Atlas, 2007.

SANTA CATARINA (Estado). Provimento $n^{\circ} 10$, de 2013. Código de Normas da Corregedoria-Geral da Justiça do Estado de Santa Catarina. Florianópolis, 8 de novembro de 2013. Disponível em: <http://cgj.tjsc.jus.br/consultas/ liberada/cncgj.pdf $>$. Acesso em: 19 de agosto de 2014. 
RIO GRANDE DO SUL (Estado). Provimento n 32, de 2006. Consolidação Normativa Notarial e Registral da Corregedoria-Geral da Justiça do Estado do Rio Grande do Sul. Porto Alegre, agosto de 2014. Disponível em: < http://cgj.tjsc. jus.br/consultas/liberada/cncgj.pdf>. Acesso em: 19 de agosto de 2014.

SÃO PAUlO (Estado). Provimento n 58 , de 1989. Tomo II das Normas de Serviço Extrajudiciais da Corregedoria Geral da Justiça do Estado de São Paulo. São Paulo, agosto de 2014. Disponível em: 〈http://www.tjsp.jus.br/ Download/Corregedoria/NormasExtrajudiciais/NSCGJTomoII.pdf $>$. Acesso em: 19 de agosto de 2014.

BRASIL. Provimento $n^{\circ}$ 37, de 2014. Corregedoria Nacional de Justiça do Conselho Nacional de Justiça. Brasília, 11 de julho de 2014. Disponível em: <http://www.cnj.jus.br/images/stories/docs corregedoria/provimentos/ provimento 37.pdf>. Acesso em: 19 de agosto de 2014.

Artigo recebido em 10/08/2015

Artigo aprovado em 28/08/2015 